related to bone health, investigated both calcium and vitamin D combined, and very limited dose-response data were available for any of the potential indicators/ outcomes. Moreover, many outcomes were studied in the context of serum 25-hydroxyvitamin D (25(OH)D) levels, whereas DRI must be specified in terms of nutrient intakes. The report evaluates, discusses and explains the evidence that was used, presented in Chapter 4 and related appendices. The entire life cycle was considered, from birth to old age and including pregnancy and lactation. Of note, the DRI for vitamin D were derived based on conditions of minimal sun exposure due to wide variability in vitamin D synthesis from UV light and the risks of skin cancer. Chapter 5 presents the reasoning for specifying and the DRI values (EAR and RDA, or AI for children up to 1 year) for each of the age-sex groups to which DRI values are applied.

The question of excess is addressed with a literature review of potential indicators/outcomes and the rationale and specification of UL (Chapter 6). The report on calcium and vitamin $\mathrm{D}$ also provides a discussion of new dietary intake data and serum $25(\mathrm{OH}) \mathrm{D}$ levels in the USA and Canada (Chapter 7), implications for special populations (Chapter 8) and research needs (Chapter 9). The source of new data on vitamin $\mathrm{D}$ intakes and serum $25(\mathrm{OH}) \mathrm{D}$ levels in the population was the National Health and Nutrition Examination Survey and Health Canada. An important finding based on these data is that serum 25(OH)D levels in the USA and Canada are, by and large, at levels consistent with intakes of vitamin $\mathrm{D}$ at the RDA level, as specified in Chapter 5. Since dietary intakes (known to often be under-reported) averaged below the new RDA levels, it seems highly likely that sunlight plus total dietary intake, together, are maintaining serum $25(\mathrm{OH}) \mathrm{D}$ levels, even in northerly regions of the USA and Canada. Throughout the text, the report discusses in detail uncertainties and caveats. The committee also authored two publications that provide a synopsis of the report directed specifically to clinical ${ }^{(9)}$ and dietetic $^{(10)}$ professionals.

In conclusion, we are sure that interested readers will find much in the new report that explains the process, the reasoning and the development of the new DRIs, and the identification of research priorities. As expected, new scientific information was the driving force for the new DRI. Although the committee was not charged with determining standardized values defining risk of deficiency, sufficiency or risk of toxicity for serum $25(\mathrm{OH}) \mathrm{D}$ for clinical laboratories, the report does note that no authoritative body has defined appropriate levels and it identifies consensus on this issue as an urgent need. Overall, while the 2011 report on DRI for calcium and vitamin $\mathrm{D}$ is now completed, it is expected that new science in the future will continue to probe the biological requirements for these important nutrients.

\author{
A. Catharine Ross \\ Department of Nutritional Sciences \\ The Pennsylvania State University \\ 110 Chandlee Laboratory, University Park \\ PA 16802, USA \\ Email: acr6@psu.edu \\ doi:10.1017/S1368980011000565
}

References

1. Institute of Medicine (2011) Dietary Reference Intakes for Calcium and Vitamin D. Washington, DC: National Academies Press.

2. Institute of Medicine (1997) Dietary Reference Intakes for Calcium, Phosphorus, Magnesium, Vitamin D, and Fluoride. Washington, DC: National Academies Press.

3. Yetley EA, Brulé D, Cheney MC et al. (2009) Dietary Reference Intakes for vitamin D: justification for a review of the 1997 values. Am J Clin Nutr 89, 719-727.

4. World Health Organization \& Food and Agriculture Organization of the United Nations (2006) A Model for Establishing Upper Levels of Intake for Nutrients and Related Substances: Report of a Joint FAO/WHO Technical Workshop on Nutrient Risk Assessment, 2-6 May 2005. http://www.who.int/ipcs/highlights/nutrientproject_may18/ en/index.html (accessed February 2011).

5. Institute of Medicine (2000) Dietary Reference Intakes: Applications in Dietary Assessment. Washington, DC: National Academies Press.

6. Institute of Medicine (2003) Dietary Reference Intakes: Application in Dietary Planning. Washington, DC: National Academies Press.

7. Institute of Medicine (2008) The Development of DRIs 1994-2004: Lessons Learned and New Challenges. Workshop Summary. Washington, DC: National Academies Press.

8. Otten JA, Pitzi Hellwig J \& Meyers LD (2006) Dietary Reference Intakes: The Essential Guide to Nutrient Requirements. Washington, DC: National Academies Press.

9. Ross AC, Manson JE, Abrams SA et al. (2010) The 2011 report on dietary reference intakes for calcium and vitamin $D$ from the Institute of Medicine: what clinicians need to know. J Clin Endocrinol Metab 96, 53-58.

10. Ross AC, Manson JE, Abrams SA et al. (2011) The 2011 report on Dietary Reference Intakes for calcium and vitamin $D$ from the Institute of Medicine: what dietetic practitioners need to know. J Am Diet Assoc (In the Press).

\section{Vitamin D}

\section{The IOM D-lemma}

Madam

It was with great anticipation that the world waited for the release of the recommendations on vitamin $\mathrm{D}$ by the Institute of Medicine (IOM), which finally made its debut in November $2010^{(1)}$. The committee relied on several large meta-analyses including those from the Agency for Healthcare Research and Quality from the USA and Canada as well as larger randomized controlled trials (RCT), and concluded that the previous recommendations made by the IOM in 1997 were woefully inadequate. The committee recognized that, at a minimum, most 
children and adults should increase their vitamin $\mathrm{D}$ intake by $200 \%$, i.e. from 5 to $15 \mu \mathrm{g}$ vitamin D/d to maintain a healthy skeleton. For adults over the age of 70 years the committee recommended $20 \mu \mathrm{g}$ vitamin $\mathrm{D} / \mathrm{d}$. The committee also appreciated that vitamin $\mathrm{D}$ is not as toxic as once thought and therefore doubled the tolerable upper limit from 50 to $100 \mu \mathrm{g} / \mathrm{d}$ for most children and all adults.

There are several thousand publications suggesting that vitamin D deficiency and insufficiency defined as 25hydroxyvitamin D level $<30 \mathrm{ng} / \mathrm{ml}$ is a pandemic affecting all populations with serious health consequences ${ }^{(2-10)}$. However the IOM concluded based on its definition of vitamin D deficiency, i.e. 25-hydroxyvitamin D $<20 \mathrm{ng} / \mathrm{ml}$, that this is a relatively rare deficiency in the USA. The IOM only recognized that vitamin D was beneficial for musculoskeletal health and dismissed a multitude of association studies and small RCT suggesting other health benefits, including improving immune and neurocognitive functions $^{(1,11,12)}$ and reducing the risk of deadly cancers ${ }^{(13,14)}$, heart disease ${ }^{(2-6)}$, autoimmune diseases ${ }^{(15)}$ and type 2 diabetes $^{(15)}$. The IOM did recognize that many tissues and cells in the body express a vitamin D receptor and that some cells including macrophages have the capability of activating vitamin $\mathrm{D}$ locally ${ }^{(16)}$. However they did not consider the health implications for why so many cells in the body would have a vitamin $\mathrm{D}$ receptor and therefore presumably require 1,25-dihydroxyvitamin D for maximum function and health.

The IOM also suggested based on a few studies that there may be a higher mortality associated with blood levels of 25-hydroxyvitamin D between $<20$ and $>30 \mathrm{ng} / \mathrm{ml}$. However, at least one of the studies it included in the analysis noted there was a lower risk of mortality for 25-hydroxyvitamin D concentrations between 30 and $49 \mathrm{ng} / \mathrm{ml}$ and a concentration $>50 \mathrm{ng} / \mathrm{ml}$ was associated with a higher risk of mortality in women but not in men ${ }^{(4)}$.

There have now been several RCT demonstrating that ingesting between 25 and $50 \mu \mathrm{g}$ vitamin $\mathrm{D} / \mathrm{d}$ and/or attaining a blood level of 25-hydroxyvitamin D $>30 \mathrm{ng} / \mathrm{ml}$ reduces risk for influenza $\mathrm{A}$ infection in schoolchildren $^{(12)}$, reduces vascular stiffness in teenagers ${ }^{(6)}$ and reduces risk of cancer in postmenopausal women by $60 \%{ }^{(14)}$. The IOM did not suggest that pregnant and lactating women need more than $15 \mu \mathrm{g}$ vitamin $\mathrm{D} / \mathrm{d}$. However in forty mother-infant pairs where $70 \%$ of the women were taking on average $15 \mu \mathrm{g}$ vitamin $\mathrm{D} / \mathrm{d}$, it was reported that $76 \%$ of the mothers and $81 \%$ of the newborns at the time of birth had 25-hydroxyvitamin D level $<20 \mathrm{ng} / \mathrm{ml}^{(17)}$; a level considered to be vitamin D deficient by the IOM committee. Furthermore it was reported that pre-eclampsia ${ }^{(18)}$ and the need for a primary Caesarean section ${ }^{(19)}$ were associated with vitamin $\mathrm{D}$ deficiency.

There is no downside to increasing vitamin D intake. The IOM in its wisdom in 1997 suggested that all children and adults up to the age of 50 years required only $5 \mu \mathrm{g}$ vitamin $\mathrm{D} / \mathrm{d}$. However, thankfully, it has now realized what most experts have been recommending: that this is totally inadequate to satisfy even bone health. It is likely that, as more RCT are reported using higher doses of vitamin D demonstrating non-skeletal beneficial effects, the next meeting will likely increase the recommendation by another threefold. To achieve a blood level of 25hydroxyvitamin $\mathrm{D}>30 \mathrm{ng} / \mathrm{ml}$, children aged 1 year and older should ingest $25 \mu \mathrm{g}$ vitamin $\mathrm{D} / \mathrm{d}$ and teenagers and all adults require $50 \mu \mathrm{g}$ vitamin $\mathrm{D} / \mathrm{d}$. A study in Finland reported that children who ingested $50 \mu \mathrm{g}$ vitamin $\mathrm{D} / \mathrm{d}$ during their first year of life had substantially reduced risk for type 1 diabetes 31 years later. Therefore the tolerable upper limit should be at least $50 \mu \mathrm{g} / \mathrm{d}$ for this age group ${ }^{(20)}$. Studies in children and teenagers have demonstrated that $50 \mu \mathrm{g}$ vitamin $\mathrm{D} / \mathrm{d}$ is safe and effective in treating and preventing vitamin $\mathrm{D}$ deficiency, and therefore a tolerable upper limit of $125 \mu \mathrm{g} / \mathrm{d}$ would be reasonable. Teenagers and all adults should be able to tolerate up to $250 \mu \mathrm{g}$ vitamin $\mathrm{D} / \mathrm{d}$ and this would be a reasonable tolerable upper limit.

Michael F. Holick

Boston University Medical Center 85 East Newton Street, M-1013

Boston, MA 02118, USA

Email: mfholick@bu.edu doi:10.1017/S1368980011000590

\section{References}

1. Committee to Review Dietary Reference Intakes for Calcium and Vitamin D (2010) Dietary Reference Intakes for Calcium and Vitamin D. Washington, DC: Institute of Medicine of the National Academies.

2. Wang TJ, Pencina MJ, Booth SL et al. (2008) Vitamin D deficiency and risk of cardiovascular disease. Circulation 117, 503-511.

3. Dobnig H, Pilz S, Scharnagl $\mathrm{H}$ et al. (2008) Independent association of low serum 25-hydroxyvitamin $\mathrm{D}$ and 1,25-dihydroxyvitamin D levels with all-cause and cardiovascular mortality. Arch Intern Med 168, 1340-1349.

4. Melamed ML, Michos ED, Post W et al. (2008) 25-Hydroxyvitamin D levels and the risk of mortality in the general population. Arch Intern Med 168, 1629-1637.

5. Melamed ML, Muntner P, Michos ED et al. (2008) Serum 25-hydroxyvitamin D levels and the prevalence of peripheral arterial disease: results from NHANES 2001 to 2004. Arterioscler Thromb Vasc Biol 28, 1179-1185.

6. Dong Y, Stallmann-Jorgenson IS, Pollock NK et al. (2010) A 16-week randomized clinical trial of 2,000 IU daily vitamin $\mathrm{D}_{3}$ supplementation in black youth: 25-hydroxyvitamin $\mathrm{D}$, adiposity, and arterial stiffness. J Clin Endocrinol Metab 95, 4584-4591.

7. Reis JP, von Mühlen D, Miller ER 3rd et al. (2009) Vitamin D status and cardiometabolic risk factors in the United States adolescent population. Pediatrics 124, e371-e379.

8. Kumar J, Muntner P, Kaskel FJ et al. (2009) Prevalence and associations of 25-hydroxyvitamin D deficiency in US children: NHANES 2001-2004. Pediatrics 124, e362-e370.

9. Sabetta JR, DePetrillo P, Cipriani RJ et al. (2010) Serum 25-hydroxyvitamin $\mathrm{D}$ and the incidence of acute viral respiratory tract infections in healthy adults. PlosOne 5, e11088. 
10. Moan J, Porojnicu AC, Dahlback A et al. (2008) Addressing the health benefits and risks, involving vitamin D or skin cancer, of increased sun exposure. Proc Natl Acad Sci USA 105, 668-673.

11. Brehm JM, Schuemann B, Fuhlbrigge AL et al. (2010) Serum vitamin D levels and severe asthma exacerbations in the Childhood Asthma Management Program study. J Allergy Clin Immunol 126, 52-63.

12. Urashima M, Segawa T, Okazaki M et al. (2010) Randomized trial of vitamin D supplementation to prevent seasonal influenza A in schoolchildren. Am J Clin Nutr 91, 1255-1260.

13. Grant WB (2002) An estimate of premature cancer mortality in the US due to inadequate doses of solar ultraviolet-B radiation. Cancer 70, 2861-2869.

14. Lappe JM, Travers-Gustafson D, Davies KM et al. (2007) Vitamin D and calcium supplementation reduces cancer risk: results of a randomized trial. Am J Clin Nutr 85, 1586-1591.
15. Holick MF (2007) Vitamin D deficiency. N Engl J Med 357, 266-281.

16. Adams JS \& Hewison M (2010) Update in vitamin D. J Clin Endocrinol Metab 95, 471-478.

17. Lee JM, Smith JR, Philipp BL et al. (2007) Vitamin D deficiency in a healthy group of mothers and newborn infants. Clin Pediatr 46, 42-44.

18. Bodnar LM, Catov JM, Simhan HN et al. (2007) Maternal vitamin $\mathrm{D}$ deficiency increases the risk of preeclampsia. J Clin Endocrinol Metab 92, 3517-3522.

19. Merewood A, Mehta SD, Chen TC et al. (2009) Association between vitamin D deficiency and primary cesarean section. $J$ Clin Endocrinol Metab 94, 940-945.

20. Hypponen E, Laara E, Jarvelin M-R et al. (2001) Intake of vitamin $\mathrm{D}$ and risk of type 1 diabetes: a birth-cohort study. Lancet 358, 1500-1503. 